BNWL-1845-14

UC-23

\title{
Pacific Northwest Laboratory Quarterly Report to Advanced Nuclear Energy Systems, Space and Special Purposes Division
}

June 30,1975

Prepared for the U.S. Energy Research and Development Administration under Contract E(45-1):1830 
NOTICE

This report was prepared as an account of work sponsored by the United States Government. Neither the United States nor the United States Energy Research and Development Administration, nor any of their employees, nor any of their contractors, subcontractors, or their employees, makes any warranty. express or implied, or assumes any legal liability or responsibility for the accuracy, completeness or usefulness of any iniormation. apparatus, product or process disclosed, or represents that its use would not infringe privately owned rights.

\author{
PACIFIC NORTHWEST LABORATORY \\ operated by \\ BATTELLE \\ for the
}

U.S. ENERGY RESEARCH AND DEVELOPMENT ADMINISTRATION

Under Contract E(45-1)-1830

Printed in the United States of America

$$
\text { Available from }
$$

National Technical Intormation Service

U.S. Department of Commerce

5285 Port Royal Road

Springfield, Virginia 2215:

Price: Printed Copy $\$ 4.00$; Microfiche $\$ 2.25$ 
BNWL-1845-14

UC -23

PACIFIC NORTHWEST LABORATORY QUARTERLY REPORT

TO ADVANCED NUCLEAR ENERGY SYSTEMS,

SPACE AND SPECIAL PURPOSES DIVISION

J. H. Jarrett - Project Manager

K. M. Harmon - Principal Investigator

June 30,1975

Battelle

Pacific Northwest Laboratories

Richland, Washington 99352 
1. Preliminary conceptual and engineering analys is studies were made of a proposed U.S. Air Force $2 \mathrm{~kW}(\mathrm{e})$ power system employing WESF ${ }^{90} \mathrm{SrF}_{2}$ capsules as a source of heat. The results showed the feasibility of such a system, but indicated that the $\mathrm{SrF}_{2}$ capsule materials might have to be changed to satisfy operating life requirements. A draft RFP for the development and testing of a prototype $2 \mathrm{~kW}(\mathrm{e})$ system was prepared and submitted to ERDA/DANES for review.

2. Dose rates from a WESF ${ }^{90} \mathrm{SrF}_{2}$ capsule were measured. Dose rates and radiation efficiencies for WESF ${ }^{137} \mathrm{CSCl}$ capsules of varying geometries were calculated.

3. A forecast of the potential supply of a number of beneficial reactor by-products was assembled.

4. A start was made on the definitions of a flow sheet for an integrated reactor by-product recovery plant.

5. Preliminary work was done on the methodology for forecasting longterm demand for reactor by-products. 


\section{CONTENTS}

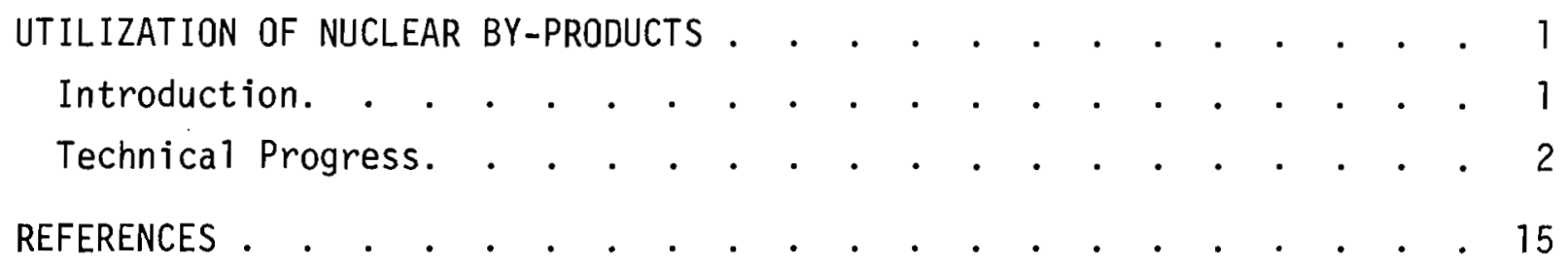




\title{
PACIFIC NORTHWEST LABORATORY \\ QUARTERLY REPORT TO ADVANCED NUCLEAR ENERGY SYSTEMS \\ SPACE AND SPECIAL PURPOSES DIVISION
}

June 30,1975

\author{
UTILIZATION OF NUCLEAR BY-PRODUCTS \\ J. H. Jarrett - Project Manager \\ K. M. Harmon - Principal Investigator
}

\section{INTRODUCTION}

The potential for beneficial use of the by-products of nuclear reactors has been studied in the United States under government and industrial sponsorship for many years. Early in FY-1975, the Pacific Northwest Laboratory (PNL) was commissioned by the USAEC to evaluate the potential use of radioactive isotopes to supply heat and power for various applications in the Cold Regions. In the spring of 1975, the scope of the PNL FY-1975 program was broadened to include the following additional activities:

1. Coordinate and perform work on the beneficial use of ${ }^{90} \mathrm{SrF}_{2}$ and ${ }^{137} \mathrm{CsCl}$ products from the Waste Encapsulation and Storage Facility (WESF) at Hanford. (WESF is operated for ERDA by the Atlantic Richfield Hanford Company, ARHCO.)

2. Estimate the potential supply of isotopes from power reactors through the year 2000, assess the potential demand for these isotopes, and evaluate the incentives for private industry to build and operate isotope recovery and encapsulation plants.

This report summarizes the work done during the fourth quarter of FY-1975 on the rest of the program. The Cold Regions work for FY-1975 is summarized in a report being prepared (BNWL-1935). 
TECHNICAL PROGRESS

Beneficial Use of WESF ${ }^{90} \mathrm{SrF}_{2}$ Capsules: Air Force Power Source

The Air Force has a potential requirement for a highly reliable $2 \mathrm{~kW}(\mathrm{e})$ electrical power system that will operate unattended for extended periods in their North American air defense network. This need could probably be satisfied by a Stirling or organic Rankine engine powered by a radioisotope heat source. PNL has undertaken the correlation of a program to develop and test such a system, powered by WESF ${ }^{90}$ Sr and using "off-the-shelf" components insofar as possible. PNL responsibilities include the following:

- Evaluate the feasibility of using WESF production ${ }^{90} \mathrm{SrF}_{2}$ capsules (Figure 1) in the heat source. If the capsule as presently designed will not meet heat source requirements, determine what changes need to be made in capsule design and work with ARHCO and ERDA to get them implemented

- Prepare and issue (through the Richland Operations Office) an RFP calling for design of an electrical power system; selection, development and testing of system components; and assembly and testing of prototype and field test systems

- Coordinate onsite (at Hanford) testing of prototype and field test assemblies

Power Systems - Heat Transfer Feasibility Study (D. H. Lester, Chemical Development)

Preliminary studies of the compatibility of $\mathrm{SrF}_{2}$ with WESF capsule materials have indicated that system design should be such that $\mathrm{SrF}_{2}$-metal interface temperatures will not exceed $800^{\circ} \mathrm{C}$ (and may have to be significantly lower). This study was undertaken to determine if established coolant conditions (temperature and flow rate) for organic Rankine and Stirling engines were compatible with WESF capsule dimensions and with an $800^{\circ} \mathrm{C}$ temperature constraint. The study was performed by calculating temperature profiles from coolant to capsule centerline for system design concepts based on: 1) individually cooled capsules (organic Rankine system 


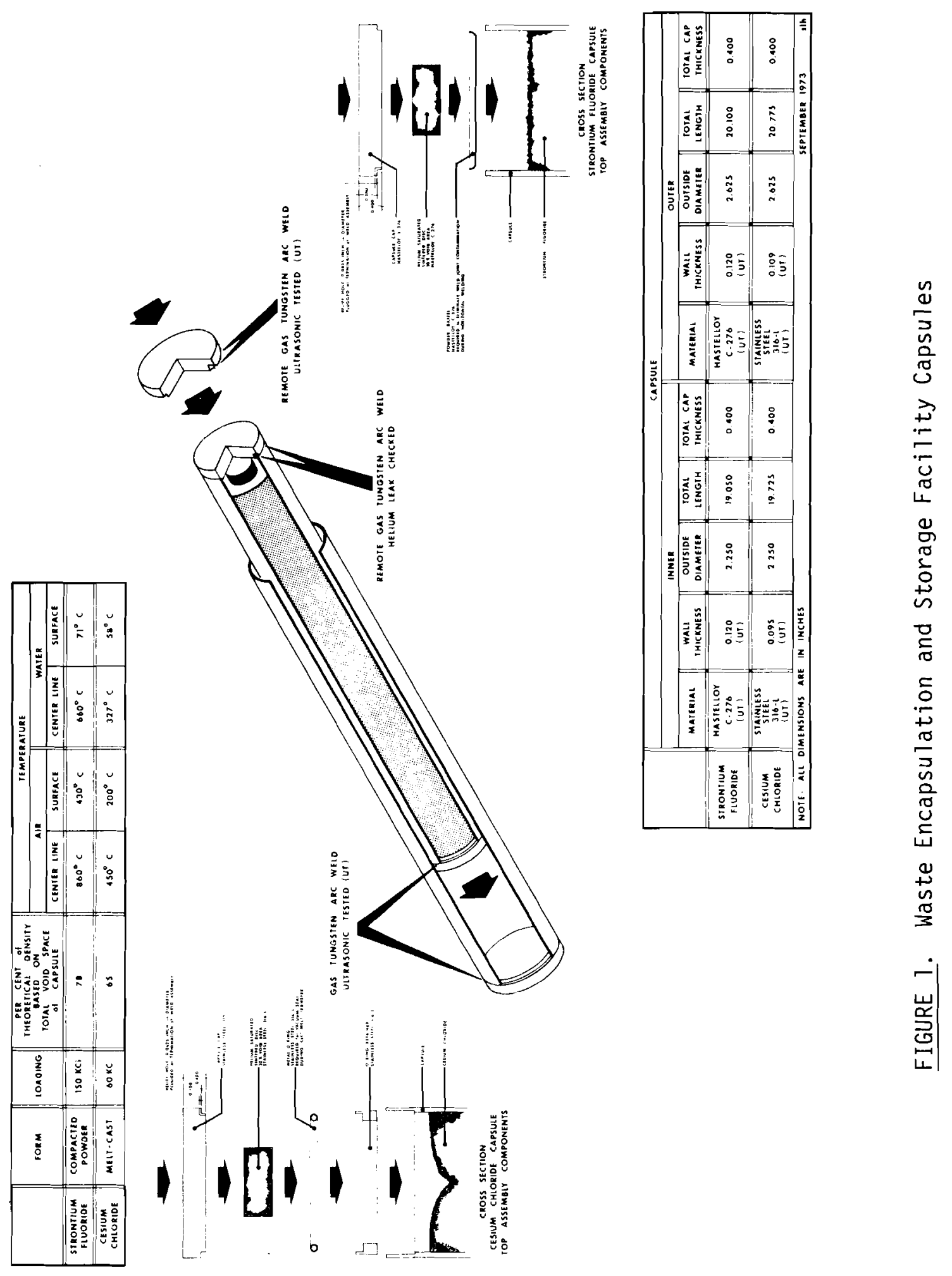


only) and 2) multiple capsules inserted in a nickel heat block (both systems). Coolant temperatures were assumed to be $338^{\circ} \mathrm{C}$ for the organic-cooled engine and $649^{\circ} \mathrm{C}$ for the helium-cooled engine. A thermal emissivity of 0.5 was assumed for all surfaces. Working fluid pressure drops were also calculated to determine percent thermal power used for pumping. No attempt was made in this early work to calculate thermal losses since the system design would be the major factor. Losses would be evaluated in future detailed designs.

Organic Rankine Cycle. A bare capsule, as fabricated, was compared with a finned capsule. The small heat transfer area of the bare capsule presents a difficult situation since the organic fluid offers film coefficients of about $1 \mathrm{Btu} / \mathrm{hr}-\mathrm{ft}^{2}-{ }^{\circ} \mathrm{F}$ or less. Table 1 shows how using fins solves the area problem. The $\mathrm{SrF}_{2}$-metal interface temperatures are well below the maximum $\left(800^{\circ} \mathrm{C}\right)$ for both types of fins and well above the maximum for the bare capsule.

TABLE 1. Temperatures in Organic-Cooled, Single Capsules

\begin{tabular}{|c|c|c|c|c|c|c|}
\hline \multirow[b]{2}{*}{ Location } & \multirow{2}{*}{\multicolumn{2}{|c|}{ Bare Capsule }} & \multicolumn{2}{|c|}{$\begin{array}{c}\text { Longitudinal } \\
\text { Fins } \\
\end{array}$} & \multicolumn{2}{|c|}{$\begin{array}{l}\text { Annular (b) } \\
\text { Fins }\end{array}$} \\
\hline & $T^{\circ} \mathrm{F}$ & & $\left.{ }^{\circ} \mathrm{F}\right)$ & $\left({ }^{\circ} \mathrm{C}\right)$ & & $\left({ }^{\circ} \mathrm{C}\right)$ \\
\hline Coolant & 640 & 338 & 640 & 338 & 640 & 338 \\
\hline Capsule Surface & 3796 & 2091 & 762 & 405 & 675 & 357 \\
\hline Liner Surface & 3820 & 2104 & 1247 & 675 & 1218 & 659 \\
\hline $\mathrm{SrF}_{2}$-Metal Interface & 3824 & 2107 & 1251 & 677 & 1222 & 661 \\
\hline Centerline & 4606 & 2441 & 2033 & 1112 & 2004 & 1095 \\
\hline
\end{tabular}

(a) 10 fins, 0.15 in. thick, 2 in. high

(b) $40 \mathrm{fins} / \mathrm{ft}, 0.2 \mathrm{in}$. thick, 2 in. high 
The capsules can be used without adding fins by placing them in a nickel block with coolant channels surrounding each capsule (Figure 2) and using some type of liquid metal bonding (Table 2). The high conductivity [32 Btu/hr- $\left.\left(\mathrm{ft}^{2} / \mathrm{ft}\right)-{ }^{\circ} \mathrm{F}\right]$ nickel serves the same purpose as fins. The liquid metal is used to fill the gap between the capsule and the block. In this concept, each capsule and its associated coolant channels occupy a section of solid nickel which is $7.5 \mathrm{in}$. in diameter and $20 \mathrm{in.}$ long. The capsules for a $10 \mathrm{~kW}$ thermal source could be placed in a $60 \times 20 \times$ 20-in. block of nicke1.

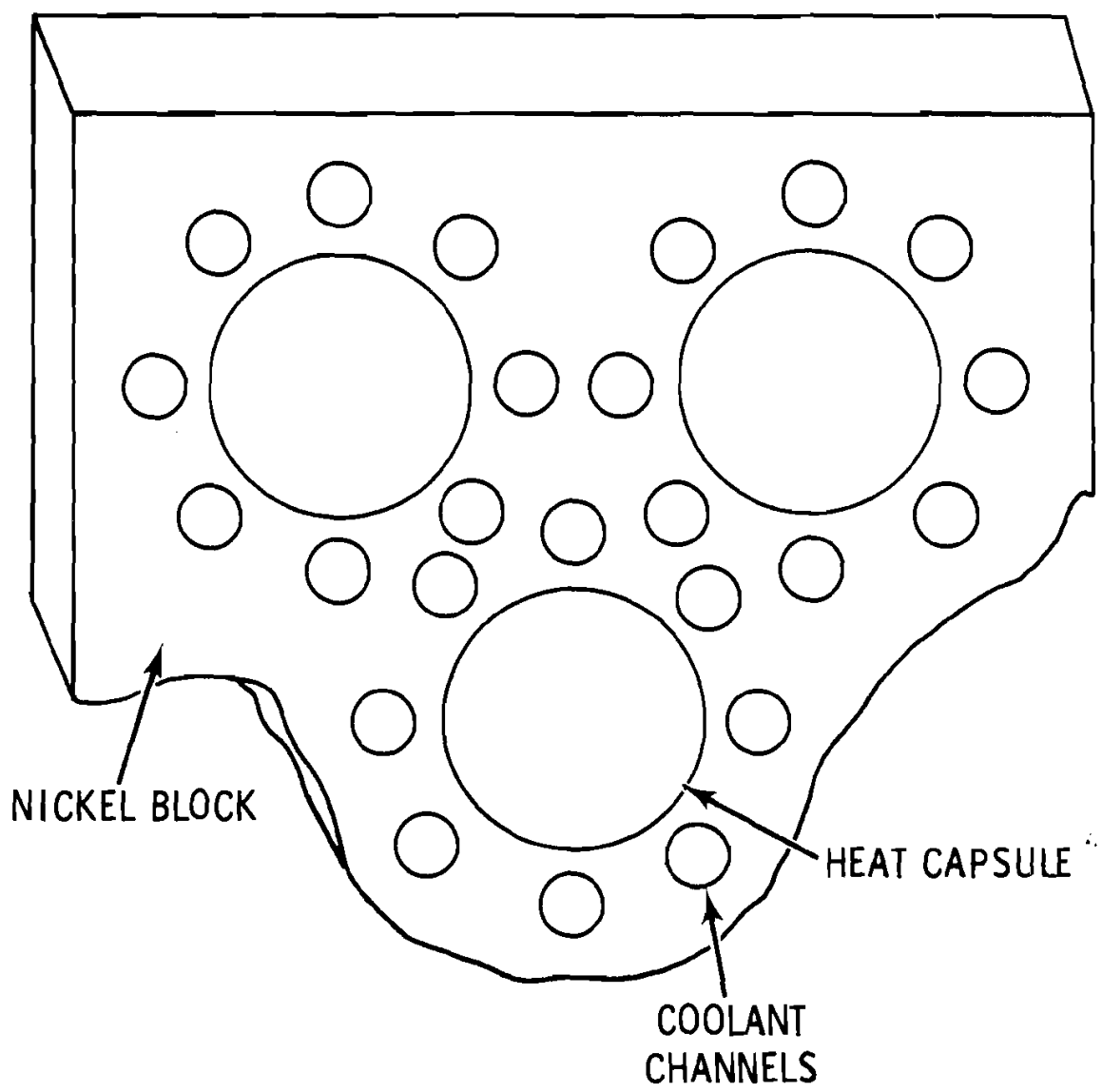

FIGURE 2. Nicke1 Block Concept 
TABLE 2. Temperatures in Organic Cooled Nickel Block Concept (a)

\begin{tabular}{|c|c|c|c|c|}
\hline & \multicolumn{2}{|c|}{ Air Gap Clearance } & \multicolumn{2}{|c|}{ Sodium Bonded } \\
\hline Location & $\left({ }^{\circ} \mathrm{F}\right)$ & $\left({ }^{\circ} \mathrm{C}\right)$ & & \\
\hline Coolant & 640 & 338 & 640 & 338 \\
\hline Coolant Wall & 1053 & 567 & 1053 & 567 \\
\hline Capsule Surface & 1350 & 732 & 1062 & 572 \\
\hline Liner Surface & 1572 & 856 & 1388 & 753 \\
\hline $\mathrm{SrF}_{2}$-Metal Interface & 1577 & 858 & 1392 & 75 \\
\hline Centerline & 2358 & 1292 & 2174 & 1190 \\
\hline
\end{tabular}

(a) 40 coolant channels, each 0.50-in. diam, arranged around capsule on a 6.5-in. diam.

$\mathrm{Flow}=6 \mathrm{lb} / \mathrm{hr}$ per capsule

Stirling/Helium Cycle. The block concept was used in studying the feasibility of the Stirling/helium system. As evident in Table 3, liquid metal bonding is likely to be necessary to obtain sufficiently low temperature gradients. The interface temperature calculated for the design used

TABLE 3. Temperatures in Helium Cooled Nickel Block Concept $(a)$

\begin{tabular}{|c|c|c|c|c|}
\hline & \multicolumn{2}{|c|}{ Air Gap Clearance } & \multirow{2}{*}{\multicolumn{2}{|c|}{$\frac{\text { Sodium Bonded }}{\left({ }^{\circ} \mathrm{F}\right)}$}} \\
\hline Location & & & & \\
\hline Coolant & 1200 & 649 & 1200 & 649 \\
\hline Coolant Wall & 1264 & 685 & 1264 & 685 \\
\hline Capsule Surface & 1484 & 806 & 1267 & 686 \\
\hline Liner Surface & 1671 & 911 & 1515 & 824 \\
\hline $\mathrm{SrF}_{2}-$ Metal Interface & 1675 & 913 & 1519 & 826 \\
\hline Centerline & 2457 & 1347 & 2301 & 1261 \\
\hline
\end{tabular}

(a) 15 coolant channels, each 0.50-in. diam, arranged around the capsule on a 4.0-in. diam.

Flow $=5 \mathrm{lb} / \mathrm{hr}$ per capsule

Pressure Drop $=80 \mathrm{psi}$ at $1200^{\circ} \mathrm{F} 200 \mathrm{~atm}$ 
as a basis for the study are slightly above the prescribed maximum. Heat block design modifications would easily lead to the goal temperature. Each capsule would occupy an envelope about $4.5 \mathrm{in}$. in diameter by $20 \mathrm{in.}$ long. Ten capsules (10 kW thermal) could be placed in a $20 \times 14 \times 20-i n$. nickel block.

Preparation of RFP (E. E. Warner, Consultant and D. Frieling, Battelle-Columbus)

A draft RFP was assembled and transmitted to DANES/ERDA for review. The work statement in the RFP includes the following major activities:

- Phase I - System definition

- Phase II - Design, development, and test (of components and of the prototype, $\mathrm{P} 1$ )

- Phase III - WESF Prototype testing (1-year life test of P1 at Hanford)

- Phase IV - Qualification testing (second prototype and field units)

- Phase V - Production

WESF SrF $_{2}$ Capsule Dosimetry (R. L. Libby and F. N. Eichner)

Dose measurements were made on a current-production WESF $\mathrm{SrF}_{2}$ waste capsule (No. 5-48) with a ${ }^{90} \mathrm{Sr}$ isotopic content of about $25 \%$. Using TLD-700 (LiF) chips, 60-min exposures gave the following results:

\begin{tabular}{cr} 
Distance from Capsule Midpoint & Dose, R/hr \\
\hline $10 \mathrm{~cm}$ & 12,100 \\
$20 \mathrm{~cm}$ & 4,900 \\
$40 \mathrm{~cm}$ & 1,600
\end{tabular}

Beneficial Use of WESF ${ }^{137} \mathrm{CSC}$ Capsules: Gamma Sources for Sewage Sludge Irradiation

Sandia Laboratory is planning a large-scale demonstration of the beneficial treatment of sewage sludge by irradiation, hopefully using WESF ${ }^{137} \mathrm{CSC} 1$ capsules for gamma sources. Since the WESF capsules were designed for long-term, underwater storage rather than for use as radiation sources, modifications in design may be required to make their use in the Sandia program attractive. Work is under way at PNL, in support of Sandia's demonstration, to optimize WESF capsule design. 
Calculations of Dose Rates and Radiation Efficiencies (R. A. Libby, Criticality Safety and Shielding Analysis)

Calculations have been completed comparing dose rates and radiation efficiencies for ${ }^{137} \mathrm{CsCl}$ in capsules of various geometries. The calculations were made for solid cylinders ranging in diameter up to $2.06 \mathrm{in}$. (current WESF design), for annular cylinders with 2.06-in. outer diameters and varying inner diameters, and for a 1-in. cylinder with two thicknesses of clad.

Calculated dose rates in water and air for two thicknesses of clad are shown in Figures 3 and 4 . Relative radiation efficiencies are shown in Table 4, and are given both in terms of: 1) an average dose rate/curie (averaged over the volume bounded by the cylinder surface and cylindrical surface which has a boundary $20 \mathrm{~cm}$ from the capsule surface) and 2) the fraction of the total source radiation absorbed in this same volume.

It is evident from these calculations that of the geometries examined, the 1-in. cylinder with $0.1-i n$. clad has the optimum radiation efficiency. Isotope Availability

Estimation of Supplies of Isotopes through 2000 AD (C. M. Heeb, Engineering Systems Analysis)

Knowledge of the character and amounts of the potentially useful isotopes present in fuels discharged from nuclear power reactors is needed to estimate possible demands for these materials. The purpose of this study was to make a preliminary estimate of the cumulative amounts produced in the U.S. civilian nuclear power economy. The time period covered is from 1972 to the year 2000 .

A large amount of detailed isotopic information for several reactor design classes has been generated previously at Battelle-Northwest (BNW) for other projects. The computer code ORIGEN was used to provide detailed information on 815 isotopes as a function of time since discharge. ORIGEN is essentially a nondimensional transmutation code equipped with several 


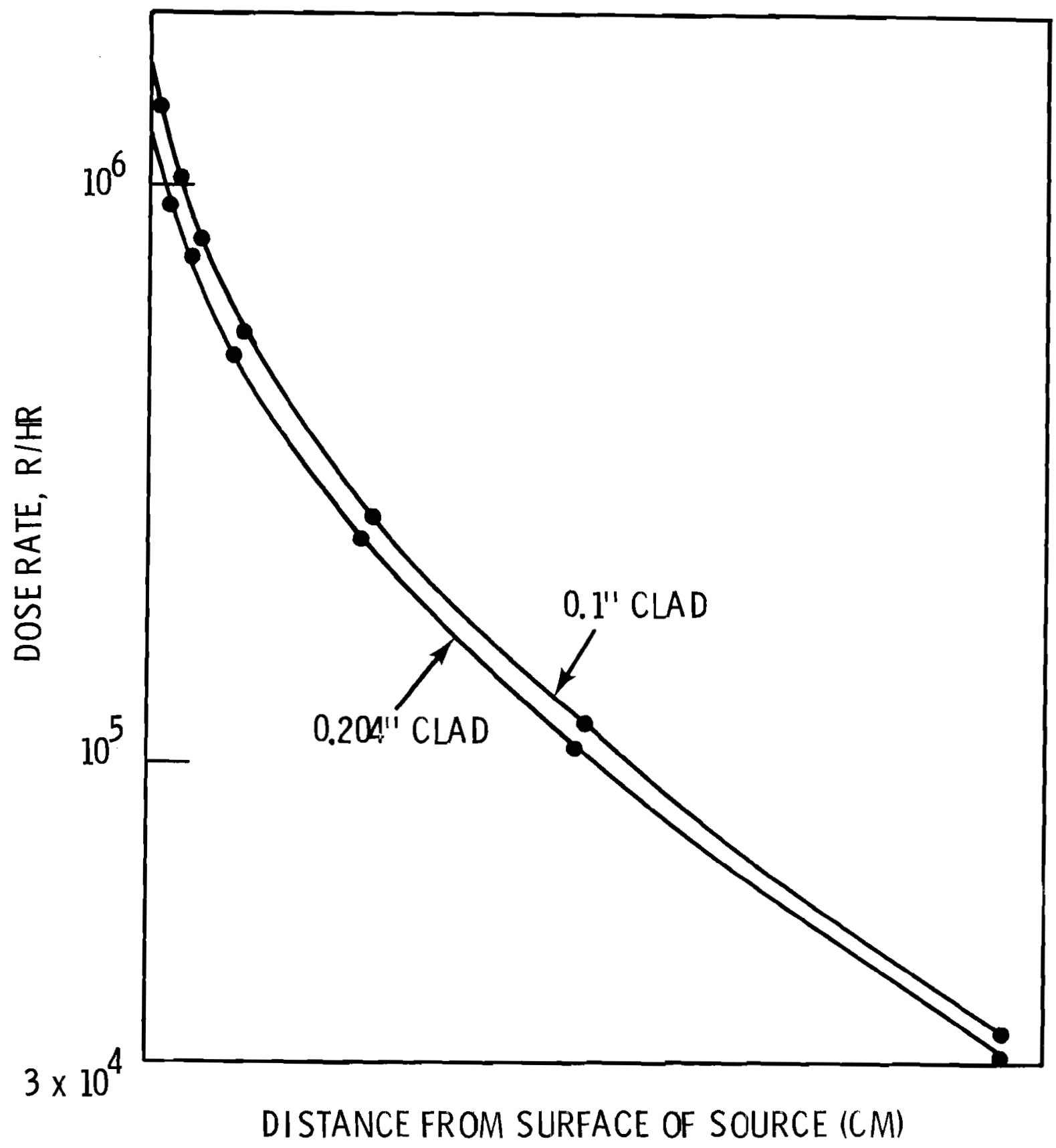

FIGURE 3. Dose Rate from CsCl Capsule in water 


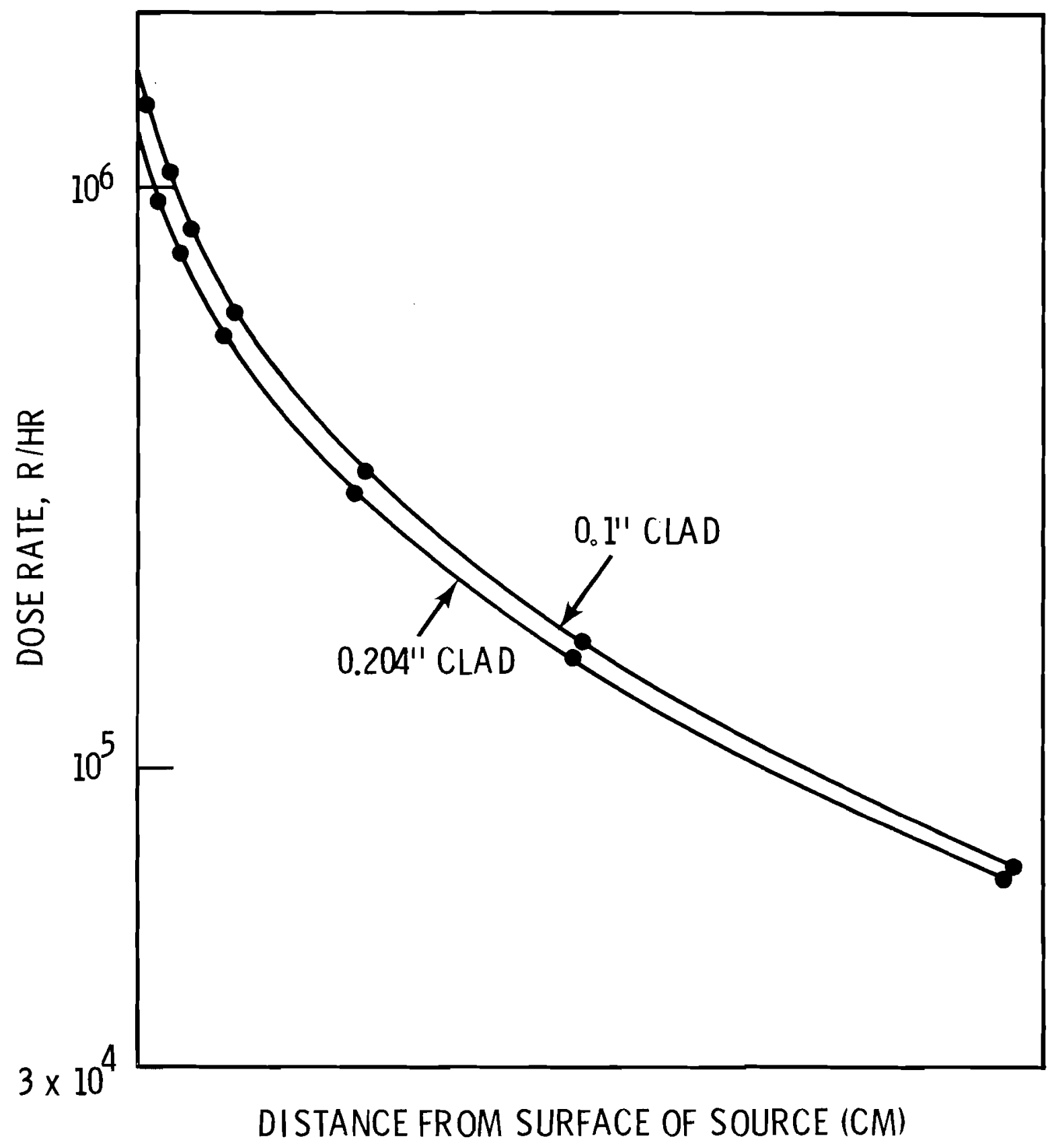

FIGURE 4. Dose Rate from CsCl Capsule in Air 
TABLE 4. Source Efficiencies

Annular Cylinders:

\begin{tabular}{|c|c|c|c|}
\hline Internal Radius $(\mathrm{cm})$ & $\begin{array}{l}\text { Clad } \\
\text { Thickness } \\
(\mathrm{cm})\end{array}$ & $\begin{array}{c}\text { Average Dose } \\
\text { Rate }(\mathrm{R} / \mathrm{hr} / \mathrm{Ci})\end{array}$ & $\begin{array}{l}\text { Fraction } \\
\text { Energy Absorbed }\end{array}$ \\
\hline $0.0^{(a)}$ & 0.5182 & 6.142 & $12.79 \%$ \\
\hline 1.27 & 0.5182 & 6.153 & $12.81 \%$ \\
\hline 1.81 & 0.5182 & 6.194 & $12.90 \%$ \\
\hline \multicolumn{4}{|l|}{ Cylinders: } \\
\hline Radius $(\mathrm{cm})$ & $\begin{array}{c}\text { Clad } \\
\text { Thickness } \\
\text { (cm) } \\
\end{array}$ & $\begin{array}{c}\text { Average Dose } \\
\text { Rate }(R / h r / C i)\end{array}$ & $\begin{array}{c}\text { Fraction } \\
\text { Energy Absorbed }\end{array}$ \\
\hline $2.6162^{(a)}$ & 0.5182 & 6.142 & 12.79 \\
\hline 1.27 & 0.5182 & 7.974 & 15.07 \\
\hline 1.27 & 0.2540 & 8.923 & 16.43 \\
\hline 0.635 & 0.5182 & 8.985 & 16.04 \\
\hline
\end{tabular}

(a) Present Capsule Configuration

massive nuclear property libraries. The constants (microscopic cross sections, decay constants, and fission yields) in each library are specific for a given reactor type. That is, the cross sections are modified somewhat to include the influence of the different neutronic environs for the various reactor types and designs.

To provide a forecast of cumulative isotopic availability, a small computer program was written to interrogate the isotopic files and to combine the retrieved specific weight (grams/metric tonne heavy metal) with a discharge scenario specified in tonnes per year for each of five reactor design types. The code does five things at each year time point: 
1) Locates the specific isotope on the file

2) Converts the gram atoms per metric ton to grams per metric ton

3) Sums the amounts available from previous years by taking the decay into account from each previous year and the number of tonnes discharged that year

4) Steps 1 through 3 are repeated for each of three reactor types (LWR, HTGR, and LMFBR) with two fuel variants in LWRs and two different LMFBR designs

5) An availability summary is prepared by adding up the amount available from each of the five reactor fuel types.

Two projections were made using two discharge scenarios and the following mix of reactor types: LWRs fueled with uranium, LWRs fueled with mixed $\mathrm{PuO}_{2}$ and $\mathrm{UO}_{2}$, HTGR on the ${ }^{233} \mathrm{U}$-thorium cycle, and two LMFBR design types. A11 of these reactor types were assumed to have reached equilibrium, i.e., constant feed composition and constant discharge exposure. One scenario represents an optimistic view (1972) of the nuclear power economy. The second scenario is based on the most pessimistic case of a set of three produced in 1974 by the Office of Planning and Analysis, AEC, and is currently judged to be the most probable. The results of this study have been summarized in Reference 1.

\section{Integrated Recovery Flow Sheet Studies (H. H. Van Tuyl, Applied} Chemistry)

Large-scale use of by-products from nuclear reactors is likely to be dependent on a commercial supply integrated with a commercial fuel reprocessing plant. Lead time for such a plant is 8 to 10 years, so the technology to be used must be developed and demonstrated long before plant startup. Processes for recovery of by-products have been developed through laboratory studies, and some processes have been demonstrated on a sufficiently large scale to permit plant design at any time. However, lowercost processes might be possible using technology which has not been 
developed this extensively. The principal effort in FY-1975 was devoted to examining new separations techniques which may represent a potential improvement over demonstrated technology. A computer-assisted literature search has been employed to get state-of-the-art references.

The most widely used method of chemical separation in the nuclear industry is solvent extraction. Its advantages include: high selectivity which assures product purity, continuous operation, versatility, speed of separation, and ease of remote operation. Solvent extraction has been the subject of extensive research and development. $(2,3)$ It has been thoroughly proven on an industrial scale at numerous nuclear facilities throughout the world. However, solvent extraction suffers from some disadvantages, including solvent flammability, toxicity of extractants, and radiation damage. Despite these disadvantages, this process has to be of primary consideration in the formulation of any nuclear product separation scheme.

Ion exchange has played a very useful role in the separation of fission products. The properties of this technique which make it especially suitable for work with radioactive substances include: comparative simplicity of operation and equipment, a high degree of flexibility, easy remote operation, and simplicity of multistage arrangements. Disadvantages associated with ion exchange processes include the large volume elutions and susceptibility to radiation damage. However, the usefulness of this process has been well demonstrated in the nuclear industry, especially in the purification of plutonium.

Refinements of ion exchange processes have involved the use of various complexing agents for elution. (4-8) This method, commonly referred to as ion exchange chromatography, has been extensively used in the separation of americium and promethium from rare earths. 0ther methods for improving ion exchange techniques are under study. Inorganic ion exchangers have been used to overcome the problem of radiation damage to synthetic resins. Hydrous oxides, salts of acids with multivalent metals, and other exchangers have been studied. Zirconium phosphate has been extensively evaluated and titanium phosphate has been successfully used to separate cesium in a pilot plant. (9) 
Several techniques are under consideration but need further study to determine the practicality of their incorporation into an industrialscale operation. Foam separation offers the advantage of volume reduction. Also, low operating and installation cost is inherent with this process. However, the process is unstable and is not continuous. Extraction chromatography has been shown to be useful in the separation and isolation of rhodium, palladium, and technetium. (10-12) However, most work with this technique has been done on a laboratory scale. Electrodialysis has been considered $^{(13)}$ but because of the many problems associated with this technique, it is not considered to be a viable method. Molten salt electrolysis also has many problems and is not considered to be practical for largescale operations.

Some newer methods usually associated with isotope separation have been investigated. Gas centrifugation, laser excitation, and diffusion separation all suffer from huge energy expenditures and are presently considered economically unacceptable to full-scale nuclear product separation.

Future efforts will be directed toward developing integrated flow sheets for by-product recovery using existing technology. No further consideration will be given to new technology at this time. A development program will be identified to translate existing laboratory technology into demonstrated plant processes.

In summary, we have reviewed the processes which show some promise for use in the separation of by-product isotopes from spent nuclear fuels. We feel that some combination of solvent extraction and ion exchange would be the most desirable method of separation in a full-scale industrial plant. While many other techniques show promise, they are not as economically or technically feasible as existing methods.

Demand Forecasting (A. M. Schneider, Contract Services)

The development of reliable forecasts of potential demand for various reactor by-products is an essential activity in any valid analysis of the 
incentives for industrial recovery of isotopes. Limited effort was applied to development of a program for making such forecasts. The program contains the following:

- Develop the format for a comprehensive picture of overal1, long-term potential demand for reactor by-products

- Review specific high-potential applications as they develop; provide or secure forecasts of related long-term demand; and incorporate these forecasts into the comprehensive demand picture

- Develop and maintain a catalog of potential uses of various isotopes and any available information concerning current or projected demand

- As funds and time permit, evaluate the lower priority uses and incorporate findings into the comprehensive demand picture.

\section{REFERENCES}

1. C. M. Heeb, The Availability of Useful Isotopes from Civilian Nuclear Power Reactors to the Year 2000, BNWL-B-435, Battelle, Pacific Northwest Laboratories, Richland, WA, 1975.

2. T. V. Healy, I. L. Jenkins, H. A. C. McKay, "Solvent Extraction in the Atomic Energy Industry," Report on the Progress in Applied Chemistry, vol. 53, pp. 681-696, 1968.

3. C. E. Stevenson, D. M. Paige, "Research and Development on Aqueous Processing," Reactor Fuel Proc., vol. 10, no. 3, pp. 241-252, 1967, and Reactor Fuel Proc. vol. 11, no. 4, pp. 201-208, 1968.

4. R. L. Moore, Fission Product Recovery Research at Battelle-Northwest, BNWL-SA-504, Battelle, Pacific Northwest Laboratories, Richland, WA, 1965.

5. E. J. Wheelwright, F. P. Roberts, U. L. Upson, L. J. Kirby, T. R. Myers, H. H. Van Tuyl, Ion-Exchange Separation of Kilocurie Quantities of High-Purity Promethium, BNWL-318, Battelle, Pacific Northwest Laboratories, Richland, WA, 1966.

6. R. L. Ritzman, R. H. Barnes, D. N. Sunderman, and J. F. Kircher, "The Purification of Multi-Curie Quantities of Promethium-147 by Ion-Exchange Using Ammonium $\alpha$-Hydroxy-Isobutyrate," J. Inorg, Nucl. Chem., vol. 28, pp. 2758-2762, 1966.

7. E. J. Wheelwright and T. R. Myers, "Investigation of NTA as a Replacement for DTPA in the Ion-Exchange Purification of Promethium," BNWL-SA1493, Battelle, Pacific Northwest Laboratories, Richland, WA, 1968. 


\section{REFERENCES (contd)}

8. E. J. Wheelwright, "A Comparison of Eluting Agents for the IonExchange Purification of Promethium," J. Inorg. Nucl. Chem., vol. 31 , pp. 3287-3293.

9. C. Beaudet and J. Cremer, "Recovery of Radioactive Cesium on Titanium Phosphate," Nucl. Appl., vol. 5, pp. 64-67, 1968.

10. J. V. Panesko, Process for Recovery of Rhodium, Palladium and Technetium from Aged Reprocessing Wastes at Hanford, ARH-733, Atlantic Richfield Hanford Company, Richland, WA, 1968.

11. J. V. Panesko, Recovery of Rhodium, Palladium, and Technetium on Strongly Basic Anion Exchange Resin, ARH-1279, Atlantic Richfield Hanford Company, Richland, WA, 1969.

12. C. A. Colvin, Recovery of Palladium from Nuclear Waste Solutions using a Packed Column of Tricapryl Ammonium Chloride on an Inert Support, ARH-1346, Atlantic Richfield Hanford Company, Richland, WA, 1969.

13. L. F. Coleman and J. R. Eliason, Ruthenium Removal from Intermediate Level Radioactive Wastes by Electrodialysis Methods, BNWL-72, Battelle, Pacific Northwest Laboratories, Richland, WA, 1965.

14. V. Kourim and 0. Vojtech, "Methods of Fission Product Separation from Liquid Radioactive Wastes," At. Energy Rev., vol. 12, pp. 215-272, 1973. 


\section{DISTRIBUTION}

No. of

Copies

OFFSITE

1

ERDA Chicago Patent Attorney

9800 S. Cass Avenue

Argonne, IL 60439

A. A. Churm

ERDA Division of Biomedical and Environmental Research Washington, DC 20545

J. N. Maddox

2

ERDA Division of Nuclear Fuel Cycle and Production Washington, $\overline{D C} 2 \overline{0545}$

F. P. Baranowski

R. W. Ramsey, Jr.

11

ERDA Advanced Nuclear Energy Systems, Space and Special Purposes Division

Washington, DC 20545

R. T. Carpenter

G. P. Dix

T. J. Dobry, Jr.

N. Goldenberg

A. P. Litman (3)

J. J. Lombardo

G. A. Newby

B. J. Rock

E. J. Wahlquist

ERDA 0ak Ridge Operations Office

P. 0. Box E

Oak Ridge, TN 37830

D. C. Davis, Jr. 
No. of

Copies

ERDA Savannah River Operations Office

P. 0. Box A

Aiken, SC 29801

R. H. Bass

T. B. Hindman

R. K. Huntoon

ERDA Technical Information Center

Department of the Army Headquarters, U.S. Army Facilities Engineering Support Agency

Fort Belvoir, VA 22060

H. Musselman, Technical Director

Electronics and Applied Physics Division Building 347.3, AERE Harwel1 0xfordshire 0X11 ORA Great Britain

E. H. Cooke-Yarborough

Genera1 Atomic Company P. 0. Box 81601

San Diego, CA 92138

H. C. Carney

General Electric Company MSVD

P. 0. Box 8555

Philadelphia, PA 19101

P. E. Brown

General Electric Company, Vallecitos Laboratory P. 0. Box 846 Pleasanton, CA 94566

G. E. Robinson

Los Alamos Scientific Laboratory P. 0. Box 1663 Los Alamos, NM 87544

S. E. Bronisz

R. A. Kent

R. N. Mulford 
Monsanto Research Corporation

Mound Laboratory (ERDA)

Nuclear Operations

P. 0. Box 32

Miamisburg, $\mathrm{OH} 45342$

W. T. Cave

Naval Nuclear Power Division

Ft. Belvoir, VA 22060

F. E. Roselle

2

Naval Facilities Engineering Command

Nuclear Power Division (FAC042)

Washington, DC 20390

T. P. Fleming

G. E. Krauter

Navy Office of the Chief of Naval Operations Washington, DC 20390

Head, Reactor Branch

4

Holifield National Laboratory

Oak Ridge, TN 37830

R. S. Crouse

J. R. DiStefano

E. Lamb

A. C. Schaffhauser

3

Teledyne Energy Systems

$110 \mathrm{~W}$. Timonium Road

Timonium, MD 21093

P. Dick

R. Hannah

$P$. Vogelberger

1

Westinghouse Astronuclear Laboratory P. 0. Box 10864

Pittsburgh, PA 15236

C. C. Silverstein 
No. of

Copies

ONSITE

2

ERDA Richland Operations Office

W. C. Johnson

B. J. Melton

7

Atlantic Richfield Hanford Company
L. I. Brecke
R. E. Isaacson
L. M. Knights
C. W. Malody
J. D. Moore
G. C. Oberg
H. P. Shaw

23

Battelle-Northwest

J. W. Bartlett

R. E. Burns

T. D. Chikalla

R. L. Dillon

J. W. Finnigan

H. T. Fullan (3)

A. J. Haverfield

J. H. Jarrett

R. S. Kemper

R. P. Marsha 11

R. W. McKee

J. M. Nielsen

R. E. Nightingale

L. D. Perrigo

A. M. Platt

J. L. Simmons

H. H. Van Tuy 1

Technical Information Files (3)

Technical Publications 